\title{
Why Africa cannot prosecute (or even educate) its way out of road accidents: insights from Ghana
}

\author{
Festival Godwin Boateng ${ }^{1 凶}$
}

The paper sheds light on the problem of the growing embracement of penal populism (fines and prison sentences) as a measure for dealing with road trauma in Africa through a case study of Ghana. It argues that the policy of hunting for rogue drivers to make roads safer in the continent is as ineffective as killing mosquitoes one by one to control malaria. The best remedy is to drain the swamps in which they breed. The swamps, in respect of road trauma in Africa, are the ineffective public transportation systems and the focus on constructing more expensive roads, which encourage the importation of more old cars, and a high dependence on privately run, deregulated commercial passenger transport sectors that are structurally embedded in driver exploitation. These factors coupled with police corruption and the traffic congestions induced by private capital-driven land-use patterns are what underlie safetyadverse driving and road transport problems generally in the continent. More fundamentally, the paper argues that the law enforcement-heavy approach to road trauma essentializes African drivers as having a danger-prone driving culture. This generates (in)discipline concerns that act as a red herring by deflecting attention from the structural factors undermining road safety in the continent: the continuing effects of neoliberal programs funded by international development bodies, and the profiteering and political interests of powerful coalitions of private transport owners' unions and public officials that have molded and entrenched the continent's road transport sectors in its present problematic forms to serve particular purposes. The paper hopes to move road safety conversations in Africa away from the present thinking that enforcing greater punishments against drivers, rather than addressing the broader societal systems whose effects manifest in the road transport sector, is "the" answer to the unacceptably high rate of carnages on the continent's roads. 


\section{Introduction}

mong the top 10 causes of deaths in the world, road injury stands alone as the only non-disease-related phenomenon. According to the World Health Organization, deaths from road accidents increased from 1.24 million per year in 2013 to 1.35 million in 2018 (WHO, 2018). The data suggest that Africa has the worst rate of road traffic deaths in the world with an unacceptably high fatality rate of 26.6 deaths per 100,000 people-nearly three times that of Europe. Some analysts suggest that the rate of road carnage in the continent could even be higher than the WHO's estimate. They peg it at some 65 deaths per 100,000 people (see Adeloye et al., 2016, for instance). It is estimated that road accidents could become the 5th leading cause of worldwide death by 2030 (Salmon and Lenné, 2015), with high levels of continuing inequality in situations, between, and within, low and middle income countries. Today, road trauma has been prioritized, and rightly so, as the serious global public health and development problem that it is. For instance, road safety, a key indicator of SDGs 3 and 11, is now a recognized global development priority. In Africa, the global capital of road trauma, various interventions are being implemented to deal with the menace. The challenge, however, is that, in a range of the countries, the preferred interventions tend to target the symptoms rather than the complex set of deep causes of the menace. This paper focuses on one of such countries in West Africa: Ghana.

Ghana has a serious problem with road fatalities, which have increased by $12-15 \%$ annually since 2008 (Dotse et al., 2019). Data from the National Road Safety Authority suggest that 2084 people were killed through road accidents in 2016 with additional 10,438 suffering various degrees of injuries (NRSC, 2016). Road trauma is among the top 10 causes of deaths in Ghana (CDC, 2019) with a socio-economic cost of $1.6 \%$ of GDP as at 2006 (Boateng, 2020a). Obeng-Odoom $(2010,2013)$ suggests that the figure could even be much higher when adjusted for the rising rate of road fatalities in the country. According to the National Road Safety Authority, the lead public statutory body responsible for road safety management in Ghana, the main causes of road accidents in the country relate to adverse driver behaviors such as over-speeding; reckless overtaking, drunk and fatigue driving (GhanaWeb, 2019a; Ministry of Transport and NRSC, 2012). The mainstream media and policy (e.g., Ghana Police Service, 2019; NRSC, 2014, 2016), as well as academic (e.g., Amo, 2014; Nyamuame et al., 2015; Sam et al., 2018) discourses on these accidentinducing risky driving practices frame the causes at the level of the drivers, which, in turn, elicit countermeasures that aim at changing or fixing them to "behave" correctly.

The countermeasures tend to involve road safety education/ campaigns, but high emphasis is often placed on law enforcement. For instance, in July 2019, the Ghana Police Service set up a "traffic enforcement team" to collaborate with Citi TV-one of the vibrant media houses in Ghana-to check "road traffic violations and other acts of indiscipline" in the country (Ghana Police Service, 2019). The intervention, dubbed "War Against Indiscipline" driving (WAI), involved the deployment of police officers and reporters from Citi TV to monitor motorists on the roads. Since July 2019, many drivers have been arrested on live TV for violating various road traffic regulations in Accra. Just within 2 days of the commencement of the operation, the state amassed some GH $\$ 258,000$ (close to US\$5000) in fines from the prosecution of some 500 drivers for various infractions (Ghanaweb, 2019b). The police have been armed with more vehicles and other operational equipment to extend the "War" from the capital (Accra) to other parts of the country (CitiTube, 2019; Nyabor, 2019).

The recent intensification of greater penalties, enforcement, and incarceration as a measure for inducing safer driving and reducing road trauma is not limited to Ghana alone, it is rapidly becoming the main and the most popular road safety measure in a range of other African countries as well. For instance, the Tanzanian government has recently proposed new traffic laws to prosecute reckless drivers and reduce road traffic accidents in the country (Mathias, 2019). In Nairobi, the capital of Kenya, not too long ago, some 60 drivers were mass-prosecuted for various traffic offenses through a joint operation by the country's National Transport and Safety Authority; National Highway Authority, the police and the traffic department (Shilitsa, 2019). Similar measures are being pursued vigorously in other parts of Africa including Nigeria (Osoteku, 2019) and Uganda (Kasirye, 2017). There is a deep-seated notion in Africa that the unacceptably high rate of road carnage in the continent would have reduced if rogue drivers were penalized severely enough. For instance, in Ghana, the War Against Indiscipline driving has been well received. There is a widespread euphoria that the country is finally cracking the whip harder enough to instill safety considerations "into the psyche and driving culture of Ghanaians [to] reduce road crashes significantly" (ModernGhana, 2019).

In other parts of the world, research (see, for instance, Novoa et al., 2010; Constant et al., 2009) has shown that toughening the consequences of road traffic offenses tends to yield some safety outcomes in both the number of drivers that are involved in injury collisions and the number of people that are injured in collisions. Could similar safety benefits accrue to Africa? Here lies the mandate of this paper: It examines whether Africa could police/punish its way out of road fatalities as the public euphoria seems to suggest - through a case study of Ghana. This is a worthwhile endeavor given the high human and other costs of road accidents in the country and the continent. A poor country and continent suffering massive losses from road trauma must spend their resources on interventions that are likely to deliver optimal and widespread sustainable safety benefits. The review was guided by the following questions:

a. What are the influences of risky driving practices or adverse driver behavior in Ghana?

b. Are the factors amenable to law enforcement measures (i.e., greater fines and incarceration)?

c. What could be learnt from the evaluation to improve road safety management in Ghana and other African countries similarly situated?

\section{Methods, materials, and analytical framework}

The analysis is informed mainly by secondary evidence from three main sources: media, scholarly, and institutional sources. The media evidence include news reports, and statements on road accidents in Ghana and Africa made by policymakers and other influential people, including presidents, parliamentarians, ministers, and police heads. The views of these powerful people and similar public sentiments are worth considering not only because they often seep into academic discourses, but also they tend to form the basis of public policy. For instance, based on a Presidential Committee report that claimed that "Indiscipline is the main contributory factor to the increasing incidents of road traffic crashes" in Ghana (Ghanaweb, 2019a), the government approved a colossal 1 billion Ghana Cedis to tackle indiscipline driving behaviors through road surveillance, sensitization, and public education (Ibrahim, 2019). The media materials were gathered with key term searches such as "road accidents in Ghana/Africa"; "road trauma in Ghana/Africa"; "road safety problems in Ghana and Africa"; "road safety policies in Ghana" on Google which, then, led the search to the stories on the website of the news agency that carried them. The use of data from media sources has 
been endorsed by many an African researcher (see e.g., ObengOdoom, 2011; Oteng-Ababio and Agyemang, 2015; Yahya, 2006) as a powerful and useful approach to exploring public discourses in the continent. Nonetheless, the potential of bias in reportage means that studies that rely on such sources should draw on a variety of media outlets to get a comprehensive picture of the topic under review. As a result, the study sourced information from both private (e.g., Ghanaweb; Peacefmonline; ModernGhana) and state-owned media agencies (e.g., GraphicOnline).

The search terms used to gather the media materials from Google were similar to those used to gather the scholarly materials except that most of the scholarly materials were sourced from the more rigorous academic search engine: Google Scholar. After reviewing the initial materials gathered, the snowball sampling technique was applied to search and incorporate some of their references. This helped to expand the scope of the materials search. The institutional materials include policy documents, road accident reports and other similar documents of government and other agencies whose endeavors focus on road safety. Materials from the National Road Safety Authority (NRSA) of Ghana, the Ghana Police Service, the Driver Vehicle License Authority (DVLA), the Ministry of Transport and the Ministry of Roads and Highways; the Federal Road Safety Commission of Nigeria, the Traffic Safety Council of Zimbabwe, the Uganda's National Road Authority, the Kenya's National Highway Authority and the Rwanda National Police and international bodies like the World Health Organization (WHO) and the US Centers for Disease Control and Prevention proved particularly useful in situating the study within the local, regional and global contexts as appropriate.

These various policy, media, and scholarly materials gathered on driver behavior and road traffic crahses (RTCs) in Ghana and Africa generally were knitted together and refracted through a political-economic framework that coherently and systematically illuminates the power relations or dynamics underlying the Ghanaian road transport sector. Based on this analysis, the study found that, contrary to opinion, the influences of risky driving behaviors in Ghana are not attitudinally-grounded-that is to say the behaviors do not result from indiscipline or moral failure on the part of the implicated drivers-to be simply resolved through sanctions or even education. At the heart of Ghana's road safety challenges are the ineffective public transportation systems and the focus on constructing more expensive roads, which encourage the importation of more old cars, and a high dependence on privately run, deregulated commercial passenger transport industry that is structurally embedded in driver exploitation. These factors, coupled with police corruption and the traffic congestions in the cities induced by private capital-driven landuse patterns are what undermine safer driving and road transport safety generally in the country. However, the present structure of Ghana's road transport sector is not a natural creation. It is the intersecting impact and extended impact of the programs and ideologies of foreign powers (read neoliberalism), as well as the profiteering and political interests of powerful coalitions of private transport owners' unions and public officials that have molded and entrenched the sector in its present problematic form.

Thus, the factors that give rise to risky driving practices and for that matter road safety challenges generally in Ghana are simultaneously subordinated to and enmeshed in broader processes that are expressions of the international, national and local sociopolitical-economic processes, factors and developments that molded and continue to shape the country's road transport sector for particular purposes. The study, based on this analysis, would argue that not only does the present driver-centric media, policy and academic approach to road trauma in Ghana create a false impression that Ghanaian drivers have a danger-prone driving culture, it also overlooks the global-local structural power dynamics, which interplay create, indeed, maintain and worsen road transport problems in the country. This is not the first study to explore Ghana's road transport problems against the backdrop of the realities of contested power relations underpinning the country's road transport sector. The originality of this study, however, (distinguished from the existing ones-e.g., OtengAbabio and Agyemang, 2015; Burchardt, 2015; Obeng-Odoom; 2010, 2013) lies with the explicit application of its politicaleconomic insight to challenge the analytical purchase of the mainstream driver-centric literature (e.g., Coleman, 2014; Haadi, 2014; Sam and Abane, 2017; Sam et al., 2020; Siaw et al., 2013) and show that the repertoire of penal populist (Ghana Police Service, 2019) and other interventions that emerge from the literature are not adequately suited to yield widespread sustainable safety benefits in the country.

Therefore, in terms of overall original contribution, the study offers a political-economic grounding that illuminates the deficiencies in the mainstream driver-centric approach to road safety practice and research in Ghana. The paper hopes to move road safety policy and research conversations in the country and Africa generally away from the present thinking that enacting and enforcing greater punitive measures against drivers, rather than addressing the broader societal systems whose effects manifest within the road sector, is "the" answer to the unacceptably high rate of road carnages on the continent's roads. After this overview, the rest of the paper is structured into 4 parts: The next section ("Etiology of risky driving in Ghana: a review of the media, policy and academic discourses") reviews and critiques the mainstream driver-centric approach to road safety in Ghana. The section argues that the focus of the approach on immediate driver errors and its attribution of the errors to drivers' character pathology or indiscipline hides more than it reveals. There is even more to learn from examining how broader system-level factors in the Ghanaian transport sector and society in general affect the behavior of drivers and overall safety outcomes in the country. The section "A 30,000 foot view of road transport problems in Ghana" draws on the political economy literature on Ghana's road transport sector broadly to theorize a more fundamental and sociological grounding for risky driving behavior and road transport problems generally in the country. The section "Discussion: can Ghana police/punish (or even educate) its way out of road trauma?" examines whether the risky driving-inducing factors discussed in the political economy literature are amenable to law enforcement. The purpose of this evaluation is to ascertain whether the recent intensification of penal populist measures could address the factors and, to that end, yield widespread sustainable road safety benefits in the country. The section "Conclusion" summarizes the main claims of the study and concludes with some comments on their implications for road safety policymaking in Ghana and other similarly situated African countries.

\section{Etiology of risky driving in Ghana: a review of the media, policy, and academic discourses}

The mainstream academic, media and public policy diagnosis of risky driving practices in Ghana such as over-speeding, reckless overtaking, drunk and fatigue driving follows a driver-centric approach - that is to say the diagnosis locates the problems at the level of drivers. Emphasis is placed on drivers' personal conduct or behavior (such as recklessness, unruliness, indiscretion, inattentiveness and poor judgment). For instance, one presidential committee argued in their report that "indiscipline is the main contributory factor to the increasing incidents of road traffic 
crashes" in Ghana (Ghanaweb, 2019a). In its 2014 road traffic crashes report, the National Road Safety Commission (NRSC) (now called National Road Safety Authority (NRSA) attributed bus and minibus crashes to drivers' indiscretion and poor judgment (NRSC, 2014). The conclusions of the presidential committee and the NRSA are consistent with the widely held notion in Ghana that the unacceptably high rate of road carnage in the country is primarily a function of the aggregates of bad attitudes of individual road users-drivers in particular. Parliamentarians (Ghanaweb, 2018); Former Presidents (PeacefmOnline, 2019); ministers of state (Gobah, 2019); the police and the media (Ghana Police Service, 2019) often attribute the carnage on Ghana's roads to driver-related factors.

The systematic literature on road trauma in Ghana too is largely driver-centric. For instance, Nyamuame et al. (2015) attribute over-speeding; overloading and disregard for road signs/ regulations to drivers' negligence and indiscipline. Amo (2014) suggests that drivers, rather than vehicles, are the cause of road fatalities in Ghana. Sam et al. (2018) make similar driver-centric claims-suggesting that about $70 \%$ of bus/minibus accidents in Ghana are due to adverse driver behavior in the form of lapses and errors (inexperience and inattention), and traffic violations (improper overtaking, improper turning, over-speeding, fatigue driving and tailgating). Sam et al. (2020) findings suggest that most passengers in Ghana rate driver behavior as the most important predictor of safety, with the implication that they are likely to attribute unsafe outcomes to driver-related factors. Hart (2013) and Okraku (2016) found that Ghanaians attribute the inundation of rickety vehicles on the roads to drivers' greed, selfishness, desire for "quick money" and lack of respect for human life. Studies such as Sam and Abane (2017); Haadi (2014); Siaw et al., (2013) and Coleman (2014) also take a driver-centric approach to road safety problems in Ghana. It is, however, worth mentioning that the view that RTCs are primarily a function of bad attitudes on the part of drivers is widely held in other African countries as well. See Udodiong (2016) for the complaints of the Federal Road Safety Commission of Nigeria; Harare (2016) for that of the Traffic Safety Council of Zimbabwe and Musinga (2016) for similar complaints by Uganda's National Road Authority. Kinyanjui (2019) and Taarifa (2017) too have reported similar concerns put forward by Kenya's National Highway Authority and the Rwanda National Police.

The framing of road transport problems around driver-related factors is not peculiar to Ghana or Africa though. Traditionally, that is how road safety discourses tend to be approached-around the behaviors of frontline actors or road users. This way of approaching road transport problems, broadly conceptualized as a road user approach, perceives human errors as the main cause of road accidents and, therefore, the individual road user is solely responsible when accidents occur. The approach is backed by several international studies (e.g., Treat et al., 1977; Sabey and Taylor, 1980; WHO, 2004) claiming that road user factors are the sole or main contributory factors to about $95 \%$ of all road accidents. Even as they usually focus on road users in general, as happening in Ghana and other parts of Africa, high emphasis is often placed on drivers. Thus, most road user focused studies tend to center on drivers. Such studies have a strong focus on specific driver-related issues that influence RTCs for the purposes of developing countermeasures (see Larsson et al., 2010). The challenge with driver-centric approaches, however, is that, as with the situation in Ghana, often, little consideration is given to the context of adverse driver behaviors and their influences. This omission is crucial because by attributing RTCs to drivers' personal attitudes without any systematic engagement with the context of the behaviors and their influences, the impression is created that Ghanaian drivers are putatively bad people or have an inherent preference for dangerous driving.

The impression sits in tension with the growing recognition in multiple fields or sectors of safety (Rasmussen, 1997; LaPorte and Consolini, 1991; Perrow, 1981; Dekker and Leveson, 2014; McDermott et al., 2018; Boateng, 2019, 2019b) that accidentinducing errors are usually not the flaws of morally or even technically or mentally deficient "bad apples" or individuals, but the, often, predictable actions and omissions that are systematically connected to the safety-critical domains in which people operate. With the realization that the true causes of accidents tend to lie within the sociotechnical context of the safety-critical domains in which people operate, road transport research and practice has taken a revolutionary turn. Today, proximate driver errors or adverse driver behaviors (such as over-speeding, inattentiveness and fatigue driving) are considered not as the causes of accidents but as the outcomes of the interactions between and among the wider societal or system-level factors (e.g., government policies, terms and conditions of labor relations and compensation systems) that underlie the sociotechnical road transport system in which drivers operate (Hughes et al., 2015; Salmon et al., 2012; Newnam et al., 2017; Thompson et al., 2015).

Thus, the focus of contemporary road safety research and practice has shifted from identifying immediate driver errors or breaches (e.g., fatigue driving, over-speeding) to the range of wider societal causes, agencies, motivations and constraints that provoke or incentivize them. This implies that the present mainstream driver-centric discourse in Ghana, which focuses on immediate driver errors and frames them as a function of bad attitudes or drivers' indiscipline hides more than it reveals. There is even more to learn from examining how broader system-level factors in the Ghanaian transport sector and society in general affect drivers' behaviors and overall safety outcomes in the country. Currently, there is little in terms of systematic studies that approach adverse driver behavior in the country from such a broader system-level political-economic perspective. Nonetheless, Boateng (2020a); Dotse et al. (2019) and Obeng-Odoom (2010, 2013), and some other cognate studies on the political economy of Ghana's transport sector offer some food for thought. The next section reviews the risky driving-inducing factors discussed in the literature with the view to examining whether the presently intensified law enforcement-heavy measures (i.e., greater fines and incarceration) could address them and, hence, yield widespread sustainable safety benefits in the country.

\section{A 30,000 foot view of road transport problems in Ghana}

Broadly, the political economy literature grounds Ghana's road transport problems at the crosscutting edges of both local/ internal and global/external factors. An important local factor emphasized in the literature as central to road transport problems and, thus, critical to establishing the grounds or structural context for the deleterious consequences of road trauma in the country is the failure of successive governments to invest meaningfully in rail and public bus transport and other infrastructure to support non-motorized transportation systems (such as bicycle lanes). This has meant that Ghanaians rely heavily on imported cars-either as owners or as passengers (Obeng-Odoom, 2013). Nonetheless, the failure of the Ghanaian state to play a leading role in the provision of transport needs and services generally and the high importation of cars into the country are also linked to economic liberalization-an external factor. In the 1980s, Ghana's economy tumbled forcing the then Provisional National Defence Council (PNDC) military government to run to the International Monetary Fund (IMF) and the World Bank for support. Attached to the support offered by 
the Bretton Woods institutions was the condition that the government liberalize the economy (Boateng, 2020b, 2020c, 2020d; Obeng-Odoom, 2013).

Further to 'advising' the PNDC government to divest itself of its holdings in transport companies, liberalization reforms also opened the floodgate for increased importation of cars into the country-a development that has since remained a marked feature of Ghana's transport sector (Burchardt, 2015; ObengOdoom, 2010, 2013). The problem, however, is that only a few number $(8 \%)$ of imported cars in Ghana are brand new. The remaining 92\% could be second-, third-, fourth-, or even fifthhand cars (Burchardt, 2015; Obeng-Odoom, 2013). Some of the vehicles are so old that they have been nicknamed "Eurocarcas". A study by the National Road Safety Commission (as it was then called) found that a significant proportion of the commercial vehicles in Ghana are old. The age profile is mostly above 5 years. Only $13 \%$ are below 5 years, about $34 \%$ are up to 10 years with those up to 15 years and above constituting over 50\% (ObengOdoom, 2013). Research has shown that fatalities in older vehicles are four times higher than in new vehicles (see RACV, 2017). Indeed, a recent analysis suggests that while old vehicles make up just $20 \%$ of road vehicles globally, they constitute one third of all fatal car crashes (RACV, 2017). With the heavy reliance on old cars for commercial and other purposes, it is not surprising that Ghana experiences high rate of road fatalities. Further to incentivizing the importation of old cars into the country, economic liberalization also propagated a certain land-use pattern, which also contributes to road safety problems.

The reforms attracted enormous private capital often multinational but also local, investments into the country. Nonetheless, the tendency for private investors to strive to enjoy the perks of economies of scale meant that almost all the investments were directed to the old generalized growth areas or industrial enclaves -i.e., the big cities particularly Accra, Tema and Kumasi (ObengOdoom, 2010, 2013). The over-concentration of investments/ business, and to that end jobs, services, trade and headquarters' of public and private institutions in the cities, has meant that almost all the traffic in Ghana move to the same place, with the attendant repercussion for gridlocks popularly called "go slow".The discourses on the adverse effects of traffic congestion in Ghana often focus on issues like productivity, air pollution and delays (Burchardt, 2015; Obeng-Odoom, 2010, 2013). Nevertheless, by holding drivers up on the road for extended periods, traffic congestions could also generate safety-adverse driving problems such as long hour and fatigue driving. Drivers, particularly commercial drivers, held up in traffic for long periods are likely to undertake aggressive and other safety-adverse driving practices to make up for lost time or potential revenue. Indeed, some empirical evidence has emerged that traffic congestions in the cities incentivize over-speeding-one of the main causes of RTCs in Ghana. For instance, some drivers submitted in Dotse et al. (2019) that they try to make up for the time they get hold up in traffic in the cities by increasing their speed on the highways-the so-called "good"roads in Ghana. One of the drivers expressed himself on the nexus between traffic congestion and overspeeding as follows:

....Driving from Accra to Kumasi should take about $4 \mathrm{~h}$ but because of the traffic you can be on the road for $6 \mathrm{~h}$. ... you can be in traffic alone for three hours and when you finally move through you want to speed to cover the time you spent in the traffic especially when the road is "good" (Emphasis added).

This may well partly explain the rather puzzling persistence of many RTCs on the "best" of Ghana's roads (the highways) (NRSC, 2016; Afukaar et al., 2003). Further to the importation of old cars and land-use patterns-induced gridlocks-thanks to neoliberal reforms-there are other political-economic dynamics and contested power relations that are critical to understanding road safety problems in Ghana. One of them is high levels of unemployment. The mainstream discourses (see e.g., BaahBoateng, 2013, 2015) on the causes of unemployment in Ghana largely focus on individual factors such as education, gender, age and marital statuses as well as people's reservation wages and locations (whether they reside in a rural or an urban setting). Nonetheless, multiple systematic studies (see e.g., Arthur, 1991; Kendie, 1998; Owusu et al., 2008; Otiso and Owusu, 2008; UNHABITAT, 2009 in Obeng-Odoom, 2013) have confirmed that the rising unemployment in Ghana and the attendant repercussions for the burgeoning informal sector are structurally embedded in bigger historical-political-economic factors and developments such as the massive reductions in public-sector employment; divestiture of public enterprises; the wage cuts and freezes and massive retrenchment exercises that came with structural adjustment reforms and have since remained key approaches of organizing socio-political-economic life by the Ghanaian state.

Regardless of the causes, studies (see, Oteng-Ababio and Agyemang, 2012, 2015) suggest that, together with the lack of viable organized public transport, the declines in opportunities for wage employment and unemployment generally in Ghana have led to a rapid growth in dangerous non-conventional transportation modes, such as the commercialization of motorcycles popularly called Okada. According to Ghana's Road Safety Authority (NRSA), Okada alone accounted for 25\% of the 1538 road fatalities recorded in the country in 2013 (Ghanaweb, 2013). Today, the chance of dying from an Okada crash in Ghana, according to the NRSA, stands at a troubling ten times higher than a car crash (Dapatem, 2020). Clearly, the proliferation of Okada in Ghana has been troubling. However, that is not the only way unemployment is influencing safety outcomes in the transport sector. The high level of unemployment in the country has also meant that, as with that of other African countries (Rizzo, 2011, 2017), Ghana's commercial car transport sector attracts a large number of lumpenproletariat seeking jobs as drivers. The situation ordinarily puts car owners in a stronger position to impose unrealistic end-of-day-sales on drivers (Obeng-Odoom, 2010, 2013; Dotse et al., 2019). As with their fellows elsewhere in Africa (Agbiboa, 2015, 2016), the precarious conditions of commercial passenger drivers in Ghana are further worsened by the ever-present bribe-demanding corrupt police officers who have created a predatory economy across the passenger transport sector by extorting monies from drivers (Boateng, 2020a). The drivers could only make enough revenue to cover operational costs and the police bribes, pay their owners, themselves, and their assistants only by increasing the number of trips or passengers per trip. They, invariably, therefore, are forced or incentivized to drive for long hours, resort to dangerous overtaking, overload their rickety vehicles and drive at dangerously high speeds with repercussions for RTCs. One driver, for instance, submitted in Dotse et al. (2019).

Many of us drivers are rushing and the problem is because of the sales you have to make...when there are more passengers like funerals on Saturday, I rush so much so I can get more money to make my sales. Even if the car is for you, after spending money at the shop you are left with something small for yourself so you have to rush whenever there are passengers and you have to work all day. You sometimes become tired but you don't have to stop.

Some commercial passenger transport drivers engaged by Klopp and Mitullah (2016); Klopp et al. (2019); Rizzo 


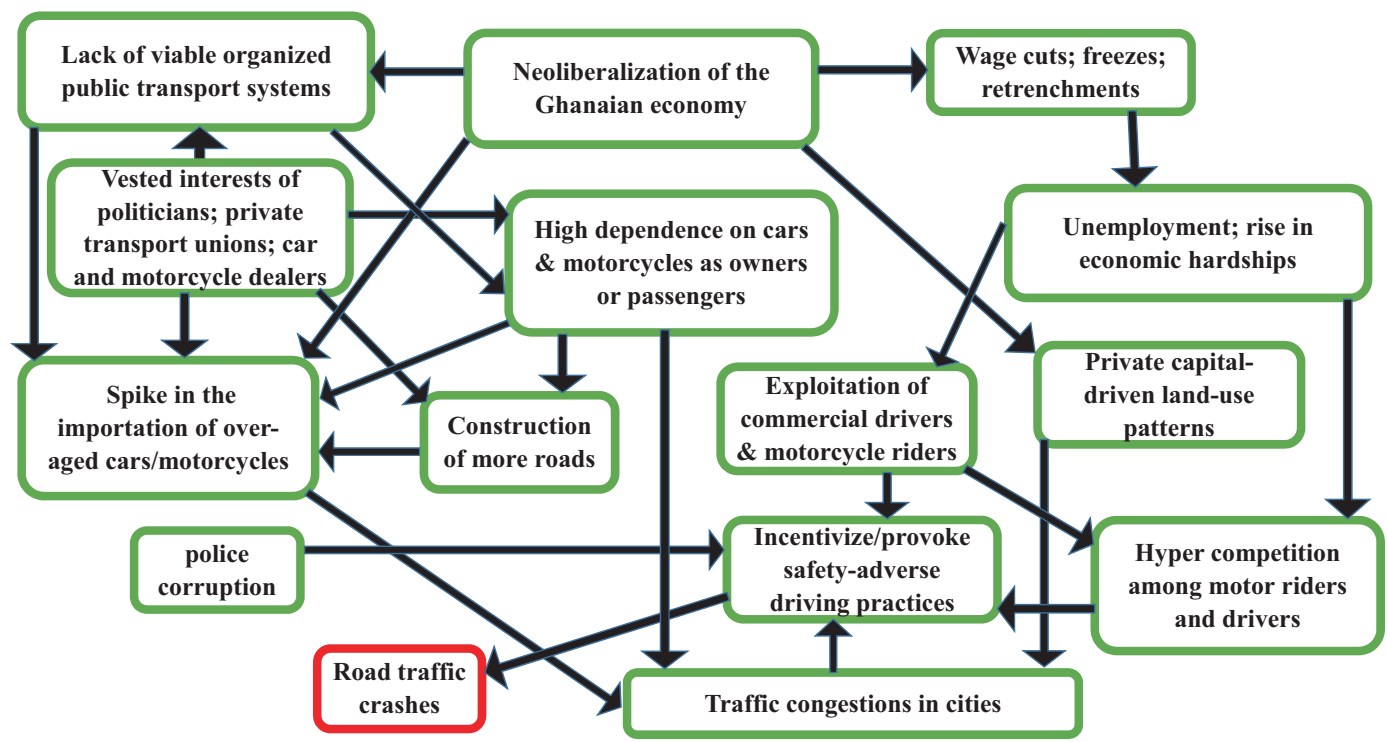

Fig. 1 Conceptual framework of influences of road trauma in Ghana.

(2011, 2017); Behrens et al. (2016); McCormick et al. (2016a, 2016b), and Agbiboa (2015, 2016) reported similar experiences in Kenya, Tanzania, South Africa, and Nigeria. Efforts by the Ghanaian authorities to improve the passenger transport sector have largely been non-committal. For instance, in April 2010, the government announced its intentions to revive the participation of the state in the commercial passenger transport sector by implementing a public-sector bus rapid transit system. However, the government balked at the plan when it was pressured by the coalition of private transport owners' unions who felt the intervention will take away their business (ObengOdoom, 2010, 2013). The plan was aborted partly because private transport owners' unions such as the Ghana Private Road Transport Union (GPRTU), the Progressive Transport Owners Association (PROTOA), the Ghana Co-operative Transport Association (GCTA) and the Ghana National Transport Owners Association (GNTOA) wield enormous political influence. Not only do they have substantial membership base that could decide elections, they also are a significant source of revenue for the government. From 1987 to 2003, the GPRTU, for instance, was collecting income tax from its members for the government. It is an arrangement that was entered into because of the lack of information about the earnings of drivers and transport owners (Obeng-Odoom, 2013). As such, successive governments found it useful to maintain the arrangement, as it provided one solution to the problem of informality, until the NPP government replaced it in 2003 with the current Vehicle Income Tax system, which requires drivers to instead pay tax on a quarterly basis (Burchardt, 2015).

Further, the members of the coalition of private transport owners' unions in the country have the potential to disrupt political rallies if, through a strike, they refuse to provide mass transportation of party supporters to rally grounds. Indeed, Ghanaian drivers have a well-documented history of disrupting the country's socio-political-economic life with strikes (see Hart, 2013). Politicians' fear of incurring the wrath of the coalition of private transport owners' unions has meant that successive governments have continued to underinvest in the public transport sector. Their focus has rather been on constructing more roads and retrofitting existing ones-which also serve political and other purposes (Obeng-Odoom, 2013). The problem, however, is that road construction may be one of the few cases in which Say's law, supply creates its own demand, applies. The construction of more roads in Ghana has encouraged the importation of even more old cars, which end up worsening the safety problems in the country (Obeng-Odoom, 2010, 2013). Per the foregoing, as summarized into Fig. 1 below, it could be argued that road accidents (but road transport problems in the broadest sense) in Ghana primarily are due to a high dependence almost exclusively on cars-either as owners or as passengers, in the context of the failure of the state to invest in alternative forms of transport, in which exploitative relationships between drivers and car owners as well as police corruption and land-use patterns-induced traffic congestions play key roles in reinforcing the prevalence of driving practices that undermine safety imperatives.

Thus, at the heart of Ghana's road transport safety challenges are how the confluence of the programs and ideologies of foreign powers and the profiteering and political interests of powerful private groups and public officials undermine investment in public transport systems, leading to a high dependence on a privately run, deregulated commercial passenger transport industry that is structurally embedded in exploitative power relations that incentivize or induce adverse driver behaviors. Ghana's road safety problems including adverse driver behaviors such as over-speeding, fatigue driving and the likes need to be understood against the backdrop of the land-use patterns as well as the structural conditions of scarcity, deprivation, inequalities and the exploitative labor relations resulting from how foreign powers and powerful local private and public interest groups have molded and entrenched the road transport sector in its present form to serve particular purposes. Whether or not the structural conditions of scarcity, deprivation, inequalities, exploitations and realities of contested power relations that create, and, indeed, maintain and worsen road safety challenges such as risky driving practices and their deleterious consequences in the country are amenable to law enforcement measures-the preferred safety strategies in Ghanaian policy circles-is the concern of the next section.

\section{Discussion: can Ghana police/punish (or even educate) its way out of road trauma?}

In response to an, hitherto, uncoordinated road safety activities in the country, the Ghanaian government, under the World Bankfinanced Transport Rehabilitation Project (TRP), initiated the Ghana Road Safety Project (GRSP) in 1988 to tackle the country's road safety problems more effectively. A decade later, Parliament, 
by ACT 567 of 1999, transformed the National Road Safety Committee under the GRSP into the National Road Safety Commission (NRSC). This move, as with the recent one that has further transformed it into an "Authority", was to provide the Commission with requisite staffing and funding to enable it to properly plan, promote and coordinate road safety activities in the country (Parliament of Ghana ACT 567, 1999). Since its establishment in 1999, the National Road Safety Authority (NRSA) has been designing and coordinating road safety programs and strategies mainly focused on accident prevention campaigns, law enforcement measures and improvement of roads. Rather, ironically, road accidents in Ghana since the establishment of the NRSA, have almost doubled from 8500 in 1999 to about 16,000 in 2012 (Siaw et al., 2013). Today, as noted earlier, road injury is among the top 10 causes of deaths in the country (CDC, 2019) with some enormous socio-economic cost: Obeng-Odoom (2013) estimates that the cost of road injuries is around $2.4 \%$ of Ghana's GDP. The findings of this research offer food for thought regarding the puzzling persistence of even more road fatalities at a time Ghana is supposedly doing road safety even "better".

The evidence considered suggests that not only are the preferred safety interventions not in tune adequately with the causes of road transport problems in the country, but also some of the interventions actually contribute to the scale of the problems in untold ways. For instance, consider factors such as the high level of unemployment proliferating the commercialization of Okada as well as forcing commercial passenger drivers to sign onto lopsided agreements with car owners, which they could only fulfill by driving for long hours; overloading buses and being reckless and aggressive on the roads. It is doubtful that enacting greater punitive measures against commercial passenger and Okada riders or intensifying road safety education could resolve those problems. Some of the drivers Dotse et al. (2019) engaged on the Behavioral influences on driver crash risks in Ghana reported that because they are forced by their precarious working conditions to drive for long hours, "...when we are feeling sleepy, we go to take "akpeteshie" [alcohol] to make us alert". Undoubtedly, increased policing and incarceration could help identify and remove some drunk and similar other drivers from the roads. However, that would not resolve the precarious conditions of their work and the job insecurities that incentivize inappropriate use of alcohol and other substances as coping mechanisms. Neither will it resolve the wider societal influences of alcohol misuse and addiction in the country with the implication that while alcohol-affected drivers will continually be caught and penalized, since they are not rehabilitated and little is done to tackle wider societal issues that contribute to its misuse and addiction, we can only expect a continued flow of alcohol-affected drivers onto the roads.

Clearly, the current embracement of penal populism and even road safety education as a measure for dealing with road trauma in Ghana could at best deliver only so much. In fact, when problematized even more broadly, it becomes clear that the challenge with road transport in Ghana is structurally embedded and inseparably connected to the high dependence almost exclusively on cars as the means of transport in the country-an unnatural problem linked to how the intersecting impact and extended impact of the programs and ideologies of foreign powers and profiteering and political interests of powerful private interest groups and public officials discourage investments in public transportation systems and encourage the construction of more expensive roads which, in turn, fuels the importation of more over-aged rickety cars for personal and commercial uses. Viewed this way, it could be argued that the present public policy of hunting for rogue drivers to make roads safer is akin to swatting mosquitoes one by one to control malaria. The problem with such reductionist approaches, as the prominent safety scientist, James Reason (2000) once noted is that the mosquitoes could still keep coming. The best remedy is to drain the swamp in which they breed. In respect of Ghana's road safety challenges, the swamp, as demonstrated in this study, are the lack of viable public transportation systems and the policy focus on constructing more expensive roads, which encourage the importation of even more old cars, and a high dependence on a privately run, deregulated commercial passenger transport sector that is structurally embedded in driver exploitation. These factors, coupled with police corruption and traffic congestions induced by private capital-driven land-use patterns, are what incentivize dangerous driving behaviors in the country.

The overall point here is that, contrary to opinion, the influences of risky driving behaviors in Ghana are not attitudinallygrounded-that is to say the behaviors do not stem from the implicated drivers' character pathology or indiscipline-to be simply resolved through sanctions or even education. They are symptoms of a complex tangle of structural factors including but not limited to the inadequate investment in public and alternative transport systems; heavy importation of over-aged cars; systemic police corruption; land-use patterns-induced traffic congestions; the high level of unemployment proliferating Okada entrepreneurialism as well as forcing commercial passenger drivers to sign onto lopsided agreements with car owners, which they could only fulfill by being reckless and aggressive on the roads-to name but a few of the structural conditions of scarcity, deprivation, inequalities, exploitations and realities of contested power relations that create, indeed, maintain and worsen road safety challenges in the country. Fixing these complex and intertwined structural drivers of road trauma in the country would require thinking beyond the present traditional domains of safety education, road engineering and the ever-popular law enforcementheavy measures of declaring "wars" on drivers and enacting greater punitive sanctions against them (Ghana Police Service, 2019; ModernGhana, 2019). A more broad enough interdisciplinary approach that breaks silos and integrates lessons and ideas from fields such as public health, workplace safety, urban planning and road safety could facilitate the emergence of innovative interventions well-suited for tackling the broader societal systems whose effects manifest inside the sociotechnical road transport system.

The analysis presented in this study does not just challenge the adequacy of law enforcement-heavy measures for addressing road transport problems in Ghana, it also raises some serious issues with the analytical purchase of the underpinning driver-centric literature. As noted earlier, with the realization that the true causes of accidents tend to lie within the sociotechnical context of the safety-critical domains that people operate (Rasmussen, 1997; LaPorte and Consolini, 1991; Perrow, 1981; Dekker and Leveson, 2014), the emphasis of road transport research has shifted from proximate driver-related errors (e.g., over-speeding) to identifying the wider societal or system-level factors (e.g., government policies, terms and conditions of labor relations and compensation systems) that incentivize such errors or fail to prevent them from resulting in crashes (Hughes et al., 2015; Salmon et al., 2012; Newnam et al., 2017; Thompson et al., 2015). Yet, as shown throughout the study, road safety research in the Ghanaian scholarly community (Nyamuame et al., 2015; Amo, 2014; Sam et al., 2018; Sam et al., 2020; Sam and Abane, 2017; Haadi, 2014; Siaw et al., 2013; Coleman, 2014) continues to focus on driverrelated factors and attributes risky driving behaviors to Ghanaian drivers' attitudinal failure without any systematic engagement with the context of the behaviors and their influences. The evidence considered in this study shows that not only does this 
attitudinal focal diagnosis of RTCs create a false impression that Ghanaian drivers have a danger-prone driving culture, it also overlooks the global-local structural power dynamics, which interplay create, indeed, maintain and worsen the range of agencies, causes, motivations and constraints that provoke or incentivize them to undertake the risky driving practices that undermine their own personal safety, the safety of their passengers and other road users.

Consider, for instance, the pervasiveness of rickety minibuses (popularly called "Tro-Tro") with squealing breaks, bald tires and rattling exhaust noises emitting thick, black smokes on Ghana's roads. Research (see Hart, 2013; Okraku, 2016) shows that the Ghanaian public attribute the problem to drivers' greed, selfishness and desire for "quick money" and lack of respect for human life. The drivers are frequently pilloried for inundating the roads with "death traps"; "safety hazards"; "Eurocarcas"; "flying coffins", and "moving morgues" (the derogative nicknames given to over-aged cars in Ghana and other parts of Africa-see Hart, 2013; Obeng-Odoom, 2010; Okraku, 2016; Agbiboa, 2020). The findings herein show, however, that the attribution of the problem to drivers' greed or personal moral failure broadly leaves out a gamut of political-economic factors unexamined. It has been shown that the problem is largely due to the failure of successive governments to invest adequately in public transportation systems with the implication of forcing the majority of the population to rely on such cars for personal use or as passengers. Even more important is the forcible neoliberal exposure of the Ghanaian transport sector to the global political economy through structural adjustment or liberalization reforms. Obeng-Odoom (2013) shows that prior to 1983, that is before the PNDC government, the IMF and World Bank set Ghana on a neoliberal path, the incremental changes in the number of imported cars was sometimes even negative (e.g.,-2184 in 1983).

Economic liberalization overturned the trend and opened the floodgate for increased importation of mainly over-aged cars into the country-a development, which has since remained a marked feature of Ghana's transport sector with attendant adverse repercussions for public health. Thus, the pervasiveness of rickety cars on Ghana's roads is best understood not in the context of drivers' character pathology (e.g., greed), but the lopsided power relations structurally embedded in the prevailing neoliberalized global political economy that allows car and oil companies in advanced capitalist economies to profit from selling over-aged cars, as a way of clearing their skies while soaking the skies and undermining public health in developing countries with toxic chemicals. The broader insight here is that the problems with rickety cars in Ghana but road safety challenges generally have a structural context: the factors that give rise to them emerge from the interplay of an array of intersecting sociopolitical-economic conditions and factors-some of which are internal (e.g., lack of viable public transportation systems) while others are externally-imposed (e.g., neoliberal structural reforms). Thus, Ghana's road transport safety problem is simultaneously subordinated to and enmeshed in broader processes that are expressions of the international, national and local sociopolitical-economic processes, factors and developments that molded and continue to shape the road transport sector for particular purposes. This is an important insight worth integrating into the mainstream driver-centric approaches to road safety research in the country. The current research agenda that focuses on immediate driver errors and frames them as a function of character pathology, as demonstrated in this study, does not just weaponize the public and state apparatuses against drivers, it also overlooks the structural conditions of scarcity, deprivation, inequalities, exploitations and realities of contested power relations that incentivize or provoke them to resort to the risky driving behaviors that undermine their own personal safety, the safety of their passengers and other road users.

\section{Conclusion}

The contemporary science on road safety considers accidentinducing driver errors (such as over-speeding, fatigue driving, reckless overtaking) not as the causes of accidents but as the outcomes of the interactions between and among the wider societal or system-level factors (e.g., government policies, terms and conditions of labor relations and compensation systems) that underlie the sociotechnical road transport system in which drivers operate. Nonetheless, in Ghana, the diagnosis follows precisely the opposite presumption: Road safety research and practice in the country focus on immediate driver errors and frame them as a function of bad attitudes or indiscipline on the part of drivers. The effect of this improper diagnosis of the problem has been the misdirection of countermeasures from the real causes of the menace. For instance, as shown in this study, at the heart of Ghana's road safety challenge is the lack of viable and variety of (public) transportation systems, which, therefore, encourages the importation of more old cars, and a high dependence on a privately run, deregulated commercial passenger transport sector that is structurally embedded in driver exploitation, and, therefore, coupled with police corruption and traffic congestions induced by private capital-driven land-use patterns, incentivize dangerous driving behaviors and their deleterious consequences in the country.

Yet, instead of aligning countermeasures with these structural conditions of scarcity, deprivation, inequalities, exploitations, and realities of contested power relations that create, and, indeed, maintain and worsen road trauma in the country, not only are Ghanaian duty bearers focused on enacting and enforcing greater punitive measures against drivers, but they also implement other policies that end up worsening the problems in untold ways. For instance, the current NPP government has declared this year (2020) the "Year of Roads" (Gyesi, 2020). However, as shown in this study, the construction of more expensive roads encourages the importation of more over-aged cars for personal and commercial uses, which end up worsening road safety problems in the country. Further, the government has recently passed a law aimed at attracting automotive manufacturers and assemblers to establish plants to manufacture and sell even more private cars in the country (see Ernst and Young LLP, 2020). The main opposition party, the NDC, has threatened to revoke the law if it wins power (Frimpong, 2020). Nonetheless, it is questionable whether their proposed alternatives could meaningfully improve the road safety situation in the country. The Party has proposed, for instance, to legalize the commercial use of Okada-a move that is also high on the current government's agenda (see Cromwell, 2020).

The call for a re-consideration of commercial use of Okada in a strictly regulated regime as discussed elsewhere (e.g., OtengAbabio and Agyemang, 2012) has some merits. It may help in overcoming congestion, provide jobs, and savings in travel time. Nonetheless, there are founded concerns (see e.g., Obeng-Odoom, 2013) about its eco-efficiency. There is also little evidence that the financially and technically stressed public institutions responsible for transport safety in the country could effectively regulate and contain the very high health and safety risks associated with Okada. These concerns become direr when account is taken of the ever-intractable issue of systemic corruption in the country. As happening with cars, corruption could worsen the already troubling safety outcomes of Okada by promoting, inter alia, improper training and licensing and fostering violations, so hazardous riding behaviors may go unchecked and mandatory maintenance and insurance may be ignored. More fundamentally, as demonstrated 
in this and other studies (e.g., Oteng-Ababio and Agyemang, 2015; Obeng-Odoom, 2013), the proliferation of Okada entrepreneurialism in cities in Ghana is primarily due to declines in opportunities for wage employment and organized public transport implying that addressing the lack of viable public transport systems, and structural unemployment could bring better and widespread sustainable road safety outcomes.

Consider efficient public transport such as rail and big buses, for instance. The evidence in countries like Japan (see ObengOdoom, 2010) suggest that, these transportation options, together with the promotion of non-motorized forms of non-commercial transport such as bicycles, have the potential to reduce meaningfully heavy reliance on private cars. Presently, it is estimated that, together with taxis, private cars occupy more than half of Ghana's road space (see Burchardt, 2015). Cutting down the use of private cars through the above measures would reduce significantly the traffic congestions in the cities-a phenomenon identified in this and other studies (e.g., Dotse et al., 2019) as a key influence of safety-adverse driving practices such as fatigue and long hour driving as well as over-speeding on the highways. Also addressing structural unemployment and the related issue of labor exploitation could restore the present lopsided power relations embedded in the commercial passenger transport sector that forces drivers to sign onto "Shylockian" (or exploitative) agreements with car owners, which they fulfill on the roads via reckless and aggressive driving practices, with attendant repercussions for crash incidents.

The proposed measures, however, should be part of a bigger agenda of gradually draining the larger neoliberal swamp breeding almost all the (mosquitoes of) structural causes of road safety problems in the country. Not just the limited role of the state in the delivery of transportation needs, but also almost all the other structural drivers of road transport problems in Ghana-i.e. the heavy importation of over-aged cars into the country; the private capital-driven land-use patterns inducing traffic congestions and the related safety-adverse driving practices; the rising levels of unemployment underlying the proliferation of Okada entrepreneurism and the lopsided power relations embedded in the commercial passenger transport sector that forces drivers to enter into exploitative agreements with transport owners, which they fulfill on the roads through reckless and aggressive driving practices-have been demonstrated to be deeply embedded and inseparably connected to structural adjustment reforms. Although the official implementation of the reforms in Ghana ended in 1993, the program laid the foundation for neoliberalism -the political-economic program that insists that the only efficient way of organizing society is to align the constitutional state with private capital accumulation rather than the solution of collective action problems (Obeng-Odoom, 2013).

Today, as one former President of the Association of Ghana Industries once noted, "Ghana's economy [has been] depressingly liberalized" (Obeng-Odoom, 2010b, p. 34). Thus, almost every sector of the country has either been outsourced, corporatized and/or privatized wholly or partially (through public-private partnerships) to private firms (local and foreign). There is a deep-seated view among Ghana's political elites that they could neoliberalize the country out of the shackles of poverty, diseases, unemployment, sanitation and the other gruesome challenges holding down the country. For instance, the policy proposals of the ruling NPP and the opposition NDC-the two major political parties in Ghanafor the ongoing 2020 general elections, as with past ones, are heavily market or private sector-driven (see NPP Manifesto, 2020; NDC Manifesto, 2020). However, as demonstrated in this study, unbridled alignment of society for the enhancement of profiteering interest of private capital tend to come with devastating consequences for human life and the environment. The study has led evidence in showing how the ideology has undermined meaningful attention towards organizing viable public transportation systems, leading to the proliferation of non-conventional transportation modes, such as Okada and a high dependence on a privately run, deregulated commercial passenger transport sector that is structurally embedded in driver exploitation, and, therefore, coupled with police corruption and traffic congestions induced by private capitaldriven land-use patterns, are incentivizing dangerous driving behaviors and their deleterious consequences in the country.

Almost all the problems underlying Ghana's road safety challenges to wit: the lack of viable public transportation systems; high level of unemployment; exploitative labor relations between drivers and transport companies or car owners and police corruption are well discernible in other African countries (see Klopp and Mitullah, 2016; Klopp et al., 2019; Rizzo, 2011, 2017; Behrens et al., 2016; McCormick et al., 2016a, 2016b; Agbiboa, 2015, 2016). This suggests that the findings from Ghana may not be culturally or geographically specific, but could be meaningful to other African countries similarly situated. Nonetheless, further research is needed for validation. Such an endeavor will be relevant for developing a stronger understanding and unraveling contextual differences between and among countries to inform well-targeted interventions that could propel the attainment of the SDGs of reducing road trauma (SDG 3.6) and making roads safer (SDG 11.2) in the continent.

\section{Data availability}

None was generated.

Received: 20 August 2020; Accepted: 14 December 2020;

Published online: 14 January 2021

\section{References}

Adeloye D, Thompson JY, Akanbi MA, Azuh D, Samuel V, Omoregbe N, Ayo CK (2016) The burden of road traffic crashes, injuries and deaths in Africa: a systematic review and meta-analysis. Bull World Health Organ 94(7):510

Afukaar FK, Antwi P, Ofosu-Amaah S (2003) Pattern of road traffic injuries in Ghana: implications for control. Inj Con Saf Promot 10(1-2):69-76

Agbiboa DE (2015) "Policing is not work: it is stealing by force": corrupt policing and related abuses in everyday Nigeria. Africa Today 62(2):95-126

Agbiboa DE (2016) 'No condition is permanent': informal transport workers and labour precarity in Africa's largest city. Int J Urban Reg Res 40(5):936-957

Agbiboa DE (2020) How informal transport systems drive African cities. Curr Hist 119(817):175-181

Amo T (2014) The influences of drivers/riders in road traffic crashes in Ghana between 2001 and 2011. Glob J Health Sci 6(4):49

Baah-Boateng W (2013) Determinants of unemployment in Ghana. Afr Dev Rev 25(4):385-399

Baah-Boateng W (2015) Unemployment in Ghana: a cross sectional analysis from demand and supply perspectives. African J Econ Manag Stud. 6(4):1-16

Behrens R, McCormick D, Mfinanga D (2016) Paratransit in African cities: operations, regulations and reform. Routledge, New York

Boateng FG (2019) A brief case for an organizational grounding for structural safety in the construction sector. Constr Manag Econ 37(8):472-47

Boateng FG (2019b) Building collapse: pathologies in cities in Ghana (Doctoral dissertation, RMIT University).

Boateng FG (2020a) "Indiscipline" in context: a political-economic grounding for dangerous driving behaviors among Tro-Tro drivers in Ghana. Humanit Soc Sci Commun 7(1):1-5

Boateng FG (2020b) A critique of overpopulation as a cause of pathologies in African cities: evidence from building collapse in Ghana. World Dev 137:105161

Boateng FG (2020c) Building collapse in cities in Ghana: A case for a historicalinstitutional grounding for building risks in developing countries. Int J Disaster Risk Reduct 50:101912. https://doi.org/10.1016/j.ijdrr.2020.101912

Boateng FG (2020d) Building safe and resilient cities: lessons from Ghana. in moving from the millennium to the sustainable development goals. Palgrave Macmillan, Singapore, pp. 267-293 
Burchardt J (2015) Order out of chaos self-management and public control of the paratransit sector: case Ghana International Association for the History of Transport, Traffic and Mobility (T2M) and the Cosmobilities Network. Santa Maria C.V. (Caserta), Italy-September 14-17, 2015. Panel theme: Shared taxi services.

Centers for Disease Control and Prevention (CDC) (2019) CDC in Ghana. Retrieved from: https:/www.cdc.gov/globalhealth/countries/ghana/pdf/ Ghana_Factsheet.pdf (Accessed: 08 Dec 20)

CitiTube (2019) MTTD to extend war against indiscipline to other regions https:// www.youtube.com/watch?v=TU8cI2qiXe8 (Accessed: 08 Dec 20)

Coleman A (2014) Road traffic accidents in Ghana: a public health concern, and a call for action in Ghana, (and the Sub-Region). Open J Prevent Med 4:822-828

Constant A, Salmi LR, Lafont S, Chiron M, Lagarde E (2009) Road casualties and changes in risky driving behavior in France between 2001 and 2004 among participants in the GAZEL cohort. Am J Public Health 99(7):1247-1253

Cromwell A (2020) We are not threatened by Mahama's claim to legalise 'Okada' Transport Minister. Retrieved from: https://www.myjoyonline.com/news/ national/we-are-not-threatened-by-mahamas-claim-to-legalise-okadatransport-minister/

Dapatem DA (2020) Legalising Okada will lead to more deaths-Consultant. Retrieved from: https://www.graphic.com.gh/news/general-news/legalisingokada-will-lead-to-more-deaths-consultant.html

Dekker SW, Leveson NG (2014) The bad apple theory won't work: response to 'Challenging the systems approach: why adverse event rates are not improving' by Dr Levitt. BMJ Qual Saf 23(12):1050-1051

Dotse J, Nicolson R, Rowe R (2019) Behavioral influences on driver crash risks in Ghana: a qualitative study of commercial passenger drivers. Traffic Inj Prev 20(2):134-139

Ernst \& Young LLP (2020) Ghana amends Customs Act to provide incentives for the automobile industry. Retrieved from: https://www.ey.com/en_gl/taxalerts/ghana-amends-customs-act-to-provide-incentives-for-the-automobileindustry. (Accessed: 08 Dec 20)

Frimpong ED (2020) What Mahama said about VW 'apotro' cars being assembled in Ghana [VIDEO]. Retrieved from: https://www.graphic.com.gh/news/ politics/what-mahama-said-about-vw-apotro-cars-being-assembled-inghana-video.html (Accessed: 08 Dec 20)

Ghana Police Service (2019) News release: police administration collaborates with CITI TV to check indiscipline on the roads. https://police.gov.gh/en/index. $\mathrm{php} /$ news-release-police-administration-collaborates-with-citi-news-tocheck-indiscipline-on-the-roads/ (Accessed: 08 Dec 20)

Ghanaweb (2013) Okada raising road fatalities-Road Safety Commission. Retrieved from: https://www.ghanaweb.com/GhanaHomePage/NewsArchive/Okadaraising-road-fatalities-Road-Safety-Commission-289761 (Accessed: 08 Dec 20)

Ghanaweb (2018) Parliament summons transport minister over rising road accidents. Retrieved from: https://www.ghanaweb.com/GhanaHomePage/ NewsArchive/Parliament-summons-transport-minister-over-rising-roadaccidents-698412 (Accessed: 08 Dec 20)

Ghanaweb (2019a) Indiscipline leading cause of road accidents-Road Safety Commission reveals. https://www.ghanaweb.com/GhanaHomePage/ NewsArchive/Indiscipline-leading-cause-of-road-accidents-Road-SafetyCommission-reveals-732820 (Accessed: 08 Dec 20)

Ghanaweb (2019b) Gov't makes GHC258, 000 from Citi TV's war against indiscipline campaign. https://www.ghanaweb.com/GhanaHomePage/NewsArchive/Gov-tmakes-GHC258-000-from-Citi-TV-s-War-Against-Indiscipline-campaign764472 (Accessed: 08 Dec 20)

Gobah T (2019) Indiscipline on our roads killing us-Transport Minister cries out. Retrieved from: https://www.graphic.com.gh/news/general-news/ghananews-indiscipline-on-our-roads-killing-us-transport-minister-cries-out.html (Accessed: 08 Dec 20)

Gyesi ZK (2020) 2020 is year of roads,-President Akufo-Addo. Retrieved from: https://www.graphic.com.gh/news/general-news/ghana-news-2020-is-yearof-roads-president-akufo-addo.html (Accessed: 08 Dec 20)

Haadi AR (2014) Identification of factors that cause severity of road accidents in Ghana: a case study of the northern region. Int J Appl Sci Technol 4(3):242-249

Harare 24 News (2016) Traffic Safety Council of Zimbabwe blames motorists. Retrieved from: http://www.harare24.com/index-id-News-zk-50994.html (Accessed: 08 Dec 20)

Hart J (2013) "One man, no chop": licit wealth, good citizens, and the criminalization of drivers in postcolonial Ghana. Int J African Hist Stud 46(3):373-396

Hughes BP, Anund A, Falkmer T (2015) System theory and safety models in Swedish, UK, Dutch and Australian road safety strategies. Accid Anal Prev $74: 271-278$

Ibrahim A (2019) Cabinet approves $₫ 1 \mathrm{~b}$ for road signs, traffic lights. Retrieved from: https://www.myjoyonline.com/news/2019/March-24th/cabinet-approves-1bfor-road-signs-traffic-lights.php (Accessed: 08 Dec 20)

Kasirye A (2017) Arrests made, vehicles impounded in new operation. Retrieved from: https://www.newvision.co.ug/new_vision/news/1458111/arrests-vehiclesimpounded-operation (Accessed: 08 Dec 20)
Kinyanjui M (2019) Indiscipline makes Mombasa Road Nairobi's deadliestKenha. Retrieved from: https://www.the-star.co.ke/counties/nairobi/2019-0320-indiscipline-makes-mombasa-roadnairobis-deadliest--kenha/ (Accessed: 08 Dec 20)

Klopp JM, Mitullah W (2016) 'Politics, policy and paratransit: a view from Nairobi'. In: Behrens R, McCormick D, Mfinanga D (eds) Paratransit in African cities: operations, regulations and reform. Routledge, New York, (2016)

Klopp JM, Harber J, Quarshie, M (2019) A review of BRT as public transport reform in African cities. VREF Research Synthesis Project Governance of Metropolitan Transport

LaPorte TR, Consolini PM (1991) Working in practice but not in theory: theoretical challenges of high-reliability organizations. J Public Adm Res Theory 1 (1):19-47. (1991)

Larsson P, Dekker SW, Tingvall C (2010) The need for a systems theory approach to road safety. Saf Sci 48(9):1167-1174

Mathias H (2019) New road traffic laws target reckless, illegal drivers. Retrieved from: https://www.thecitizen.co.tz/news/New-road-traffic-laws-target-reckless-illegaldrivers/1840340-5252908-132lo8m/index.html (Accessed: 08 Dec 20)

McCormick D, Mitullah W, Chitere P, Orero R, Ommeh M (2016b) 'Matatu business strategies in Nairobi'. Paratransit in African cities: Operations, Regulations and Reform. Routledge, New York

McCormick D, Herrie S, Mfinanga D, Behrens R, McCormick D, Mfinanga D (2016a) 'The nature of paratransit operations'. Paratransit in African cities: operations, regulations and reform. Routledge, New York, (2016)

McDermott V, Zhang RP, Hopkins A, Hayes J (2018) 'Constructing safety: investigating senior executive long-term incentive plans and safety objectives in the construction sector'. Const Manag Econ 36(5):276-290

Ministry of Transport \& NRSC (2012) Final report a study to determine the magnitude of driving under the influence of alcohol and its impact on road safety in Ghana. Retrieved from: http://www.nrsc.gov.gh/images/ publications/NRSC_PUBLICATION.pdf (Accessed: 08 Dec 20)

ModernGhana (2019) Two new police vehicles to fight against indiscipline campaign. https://www.modernghana.com/news/945705/two-new-police-vehicles-to-fightagainst-indiscipl.html (Accessed: 08 Dec 20)

Musinga N (2016) Indiscipline is the main reason why there's road carnage on roads especially Masaka road, Musinga notes. Retrieved from: https://twitter. com/ntvuganda/status/758167007988740096 (Accessed: 08 Dec 20)

National Democratic Congress (NDC) (2020) Jobs, prosperity and more: The people's manifesto (2021-2025). NDC: Accra

National Road Safety Commission (NRSC) (2014) Road traffic crashes in Ghana. NRSC, Accra

New Patriotic Party (NPP) (2020) Leadership of service: protecting our progress, transforming ghana for all (2020 Manifesto). NPP: Accra

Newnam S, Goode N, Salmon P, Stevenson M (2017) Reforming the road freight transportation system using systems thinking: an investigation of Coronial inquests in Australia. Accid Anal Prev 101:28-36

Novoa AM, Pérez K, Santamariña-Rubio E, Marí-Dell'Olmo M, Ferrando J, Peiró R, Borrell C (2010) Impact of the penalty points system on road traffic injuries in Spain: a time-series study. Am J Public Health 100(11):2220-2227

NRSC (2016) Road traffic crash statistics-2016: General overview of the road safety situation: http://www.nrsc.gov.gh/images/statistics/ROAD-TRAFFIC-CRASHSTATISTICS-2016.pdf (Accessed: 08 Dec 20)

Nyabor J (2019) Citi TV's war against indiscipline campaign to continue into 2020 Retrieved from: https://citinewsroom.com/2019/07/citi-tvs-war-againstindiscipline-campaign-to-continue-into-2020/ (Accessed: 08 Dec 20)

Nyamuame GY, Aglina MK, Akple MS, Philip A, Klomegah W (2015) Analysis of road traffic accidents trend in Ghana: causing factors and preventive measures. Int J Eng Sci Manag Res 2(9):127-132

Obeng-Odoom F (2010) Drive left, look right: the political economy of urban transport in Ghana. Int J Urban Sustain Dev 1(1-2):33-48

Obeng-Odoom F (2011) The informal sector in Ghana under siege. J Dev Soc 27(34):355-392

Obeng-Odoom F (2013) Governance for pro-poor urban development: lessons from Ghana. Routledge, NY

Okraku TK (2016) "Biribiara Wo Ne Mmere"(everything has its time): exploring changing perceptions of transportation on film from the colonial gold coast to contemporary Ghana. Afr Today 62(4):45-64

Osoteku O (2019) Oyo government to prosecute 25 over drunk-driving. Retrieved from: https://www.von.gov.ng/oyo-government-to-prosecute-25-over-drunkdriving/ (Accessed: 08 Dec 20)

Oteng-Ababio M, Agyemang E (2012) Virtue out of necessity? Urbanisation, urban growth and Okada services in Accra, Ghana. J Geogr Geol 4(1):148

Oteng-Ababio M, Agyemang E (2015) The okada war in urban Ghana: a polemic issue or policy mismatch? Afr Stud Quart 15(4):25

Parliament of Ghana (1999) ACT 567. Retrieved from: https://opencontentghana. files.wordpress.com/2013/11/national-road-safety-commission-act-1999-act567.pdf (Accessed: 08 Dec 20) 
PeacefmOnline (2019) Indiscipline \& sheer recklessness cause of road deaths-rawlings. http://www.peacefmonline.com/pages/local/news/201903/378485.php (Accessed: 08 Dec 20)

Perrow C (1981) Normal accident at Three Mile Island. Society 18(5):17-26

RACV (2017) New analysis: fatality rate four times higher in an older vehicle. Retrieved from: https://www.racv.com.au/membership/member-benefits/ royalauto/archive/fatality-rate-four-times-higher-in-an-older-vehicle.html (Accessed: 08 Dec 20)

Rasmussen J (1997) Risk management in a dynamic society: a modelling problem. Saf Sci 27(2/3):183-213

Reason J (2000) Human error: models and management. BMJ 320(7237):768-770

Rizzo M (2011) 'Life is war': informal transport workers and neoliberalism in Tanzania 1998- 2009. Dev Change 42(5):1179-1206

Rizzo M (2017) Taken for a ride: grounding neoliberalism, precarious labour, and public transport in an African Metropolis. Oxford University Press, Oxford

Sabey B, Taylor H (1980) The known risks we run: the highway. transport and road research laboratory supplementary report No. 567. Transport and Road Research Laboratory, Crowthorne, England.

Salmon PM, Lenné MG (2015) Miles away or just around the corner? Systems thinking in road safety research and practice. Accid Anal Prevent 74:243

Salmon PM, McClure R, Stanton NA (2012) Road transport in drift? Applying contemporary systems thinking to road safety. Saf Sci 50(9):1829-1838

Sam EF, Abane AM (2017) Enhancing passenger safety and security in Ghana: appraising public transport operators' recent interventions. J Sci Technol (Ghana) 37(1):101-112

Sam EF, Brijs K, Daniels S, Brijs T, Wets G (2020) Testing the convergent-and predictive validity of a multi-dimensional belief-based scale for attitude towards personal safety on public bus/minibus for long-distance trips in Ghana: A SEM analysis. Transp Policy 85:67-79

Sam EF, Daniels S, Brijs K, Brijs T, Wets G (2018) Modelling public bus/minibus transport accident severity in Ghana. Accid Anal Prevent 119:114-121

Shilitsa J (2019) Over 60 drivers arrested, handed instant fines on KakamegaWebuye highway. Retrieved from: https://www.standardmedia.co.ke/article/ 2001337477/over-60-drivers-arrestedfined-in-kakamega-matatu-crackdown (Accessed: 08 Dec 20)

Siaw NA, Duodu E, Sarkodie KS (2013) Trends in road traffic accidents in Ghana; implications for improving road user safety. Int J Humanit Soc Sci Invent 2 (11):31-35

Taarifa (2017) Rwanda police reveals who is causing more accidents on highways. Retrieved from: https://taarifa.rw/2017/05/22/here-is-what-expertsare-discussing-about-poor-african-traders/ (Accessed: 08 Dec 20)

Thompson J, Newnam S, Stevenson M (2015) A model for exploring the relationship between payment structures, fatigue, crash risk, and regulatory response in a heavy-vehicle transport system. Transp Res Part A: Policy Pract 82:204-215

Treat JR, Tumbas NS, McDonald ST, Shinar D, Hume RD, Mayer RE, Stansifer RL, Castellan NJ, (1977) Tri-level study of the causes of traffic accidents. Indiana
University Final Report to the US DOT, Report No. DOT-HS-034-3-535- 77TAC

Udodiong I (2016) 'Indiscipline is responsible for accidents along Lagos-Ibadan Expressway'-FRSC. Retrieved from: https://www.pulse.ng/news/road-trafficcrashes-indiscipline-isresponsible-for-accidents-along-lagos-ibadan/zmznt68 (Accessed: 08 Dec 20)

World Health Organization (WHO) (2018) Global status report on road safety 2018. World Health Organization, Geneva

World Health Organization (2004) World Report on Road Traffic Injury Prevention. WHO Library 448 Cataloguing-in-Publication Data

Yahya S (2006) Unmaking the slums: emerging rules, roles, and repertoires. Stetson Law Rev 36:121-147

\section{Acknowledgements}

I am grateful to the following people for providing helpful comments on earlier drafts of the paper: Mrs Magdalene Nkrumah Boateng of Agricultural Development Bank, Makola-Accra; Dr. Jackie Klopp of the Earth Institute of Columbia University, New York.

\section{Competing interests}

The author declares no competing interests.

\section{Additional information}

Correspondence and requests for materials should be addressed to F.G.B.

Reprints and permission information is available at http://www.nature.com/reprints

Publisher's note Springer Nature remains neutral with regard to jurisdictional claims in published maps and institutional affiliations.

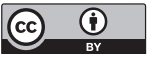

Open Access This article is licensed under a Creative Commons Attribution 4.0 International License, which permits use, sharing, adaptation, distribution and reproduction in any medium or format, as long as you give appropriate credit to the original author(s) and the source, provide a link to the Creative Commons license, and indicate if changes were made. The images or other third party material in this article are included in the article's Creative Commons license, unless indicated otherwise in a credit line to the material. If material is not included in the article's Creative Commons license and your intended use is not permitted by statutory regulation or exceeds the permitted use, you will need to obtain permission directly from the copyright holder. To view a copy of this license, visit http://creativecommons.org/licenses/by/4.0/.

(c) The Author(s) 2021 